\title{
Composition of staphylococcal bi-component toxins determines pathophysiological reactions
}

\author{
B. KÖNIG, G. PRÉVOST* and W. KÖNIG
}

Medizinische Mikrobiologie und Immunologie, Infektabwehr, Ruhr-Universität Bochum, Bochum, Germany and * Laboratoire de Toxinologie Bacteriénne et de I'Institut de la Faculté de Médecine, Strasbourg, France

\begin{abstract}
Staphylococcus aureus produces numerous bi-component toxins, e.g., Panton-Valentine leukocidin (Luk-PVL) and $\gamma$-haemolysin, which consist of type $S$ and $F$ proteins. Previous studies showed that Luk-PVL induces inflammatory mediator release from human granulocytes that might reflect the in-vivo effects, e.g., dermonecrosis by LukPVL. Clinical isolates not only harbour the two genes coding for Luk-PVL (S-protein: LukS-PVL, F-protein: LukF-PVL) but also the three genes encoding $\gamma$-haemolysin (Sprotein: HIgA, HIgB; F-protein: HIgC). The interaction of all the possible potential toxins with human granulocytes was studied with regard to the generation of oxygen metabolites (chemiluminescence response), enzyme activity ( $\beta$-glucuronidase) and histamine release as well as interleukin (IL)-8 generation. The data clearly show that the individual subunits $(S, F)$ differ in their activities. The following activities were obtained for the $S$ components: LukS-PVL $>$ HIgC $>$ HIgA; the F components LukFPVL and HIgB were similarly active. Thus, the toxins LukS-PVL/LukF-PVL and LukSPVL/HIgB were the most potent inducers of inflammatory mediator release from human granulocytes, followed by HIgC/LukF-PVL and HIgC/HIgB and to a lesser degree by the toxins $\mathrm{HIgA} / \mathrm{LukF}-\mathrm{PVL}$ and $\mathrm{HIgA} / \mathrm{H} \operatorname{lgB}$. The data indicate that class $\mathrm{S}$ components and class $\mathrm{F}$ components are interchangeable and give toxins with genuine biological activities.
\end{abstract}

\section{Introduction}

Synergohymenotropic toxins (SHT toxins) are bicomponent, non-associated exoproteins (class $\mathrm{S}$ and class $\mathrm{F}$ components) that are able to induce pores in membranes synergically [1]. They promote the release of inflammatory mediators [1].

SHT toxins constitute a family of toxins including three kinds of loci. (1) $\gamma$-Haemolysin and its variants from Staphylococcus aureus are made up of two class $\mathrm{S}$ (HlgA, HlgC) components and a class $\mathrm{F}$ ( $\mathrm{HlgB})$ component [2]. One of the genes $(h \lg A)$ is separately transcribed, the other two $(h \lg C$ and $h \lg B$ ) are cotranscribed. The haemolysin is leukotoxic and haemolytic in vitro [3]. (2) The Panton-Valentine leukocidin (PVL) consists of only one class S (LukS-PVL) component and one class F (LukF-PVL) component [2]. It is highly leukotoxic and dermonecrotic for rabbit skin. The components $\mathrm{HlgA}$ and $\mathrm{HlgC}$ are structurally and functionally similar to LukS-PVL,

Received 7 June 1996; revised version accepted 21 Oct. 1996.

Corresponding author: Professor W. König. whereas HlgB is structurally and functionally close to LukF-PVL [1, 4, 5]. Class $\mathrm{S}$ components have only $20-22 \%$ sequence similarity with $S$. aureus $\alpha$ haemolysin, whereas class $\mathrm{F}$ components have $27-$ $28 \%$ sequence similarity [4].

PVL and $\gamma$-haemolysin genes are not equally distributed amongst $S$. aureus strains; $\gamma$-haemolysin genes are constitutive of most $S$. aureus isolates $(99 \%$ of clinical isolates) [6] but PVL genes are rarely encountered in randomly selected isolates $[7,8]$. PVL-producing $S$. aureus strains are strongly associated with furunculosis. Leukotoxicity is not the sole characteristic of these toxins; their major virulence role would be the compromising of cellular immunity. At the molecular level, sublytic amounts of PVL have been shown to induce granule secretion $[9,10]$ from human polymorphonuclear leucocytes (PMNL) and the release of leukotriene $\mathrm{B}_{4}$ as well as interleukin (IL)-8 [11]. These mediators may be responsible for the toxin effects observed when the toxins are injected intradermally $[7,8,11]$. The role of $\gamma$-haemolysin in inflammatory mediator release is still unknown.

Recently it has been reported that PVL-producing 
strains also have the genes encoding and producing $\gamma$ haemolysin [12]. Thus, six possible combinations of type $\mathrm{S}$ and type $\mathrm{F}$ proteins occur in such strains and potentially could lead to six toxins of different significance in bacterial pathogenesis. This study investigated the interaction of all the possible toxin combinations with human granulocytes - cells of the first defence line. Therefore, inflammatory mediators of the non-specific host defence which play an important role in host defence against invading microorganisms or toxins were analysed. The generation of oxygen metabolites (chemiluminescence response), enzyme activity ( $\beta$-glucuronidase) and histamine release, as well as IL-8 generation, were studied.

\section{Materials and methods}

\section{Toxin production}

The three components of $\gamma$-haemolysin (HlgA, HlgB, $\mathrm{HlgC}$ ) and the two components of PVL (LukS-PVL, LukF-PVL) (Table 1) were simultaneously purified from culture supernates of $S$. aureus ATCC 49775 as described previously $[3,7,11]$. Purified proteins were tested by immunoprecipitation with affinity-purified antibodies against the toxin subunits. The precise characterisation of the purified fractions was performed by $\mathrm{N}$-terminal sequencing. $\mathrm{S}$ and $\mathrm{F}$ components by themselves had no activity with regard to inflammatory mediator release or to cytokine release. Thus, they were not contaminated with LPS or superantigens.

\section{Buffer}

The buffer used for washing the cells and for assay of mediator release consisted of $137 \mathrm{mM} \mathrm{NaCl}, 8 \mathrm{mM}$ $\mathrm{Na}_{2} \mathrm{HPO}_{4}, 3 \mathrm{mM} \mathrm{KCl}$ and $3 \mathrm{mM} \mathrm{KH} \mathrm{KHO}_{4}, \mathrm{pH} 7.4$ (modified Dulbecco's PBS).

\section{Cell viability}

Cell viability was determined by trypan blue exclusion.

Preparation of PMNLs and a human lymphocytemonocyte-basophil cell suspension (LMB)

PMNLs were isolated from $200 \mathrm{ml}$ of heparinised blood $(15 \mathrm{U} / \mathrm{ml})$ from three healthy donors by separation on a Ficoll-metrizoate gradient followed by

Table 1. Nomenclature for staphylococcal Panton-Valentine-leukocidin and $\gamma$-haemolysin

\begin{tabular}{lll}
\hline & \multicolumn{2}{c}{ Current name of } \\
\cline { 2 - 3 } Current name of toxins & genes & protein components \\
\hline $\begin{array}{l}\text { Panton-Valentine- } \\
\text { leukocidin }\end{array}$ & $\operatorname{lukS-PV}$ & LukS-PV (S component) \\
(PVL) & $\operatorname{lukF-PV}$ & LukF-PV (F component) \\
$\gamma$-Haemolysin & $h l g A$ & HlgA (S component) \\
& $h l g B$ & HlgB (S component) \\
& $h l g C$ & HlgC (F component) \\
\hline
\end{tabular}

dextran sedimentation as described previously [13]. The PMNLs were washed twice by centrifugation at $300 \mathrm{~g}$ and the method yielded $>95 \%$ pure PMNL. The LMB fraction containing 84.6 SD 4.6\% lymphocytes (L), $14.2 \mathrm{SD} 4.1 \%$ monocytes (M) and $1.2 \mathrm{SD} 0.5 \%$ basophilic granulocytes (B) was isolated by Ficollmetrizoate sedimentation and washed twice with PBS by centrifugation at $300 \mathrm{~g}$ [11]. The LMB cell suspension served as a source for basophilic granulocytes (histamine release) and for monocytes (IL-8 generation). The cells were diluted to a final concentration of $2 \times 10^{7}$ cells $/ \mathrm{ml}$ in PBS.

\section{Studies on cellular activation}

To study enzyme activity, histamine release and IL-8 generation, human PMNL $\left(1 \times 10^{7}\right.$ cells $\left./ 500 \mu 1\right)$ or human LMB $\left(5 \times 10^{6}\right.$ cells $\left./ 500 \mu \mathrm{l}\right)$ were stimulated in the presence of $\mathrm{Ca}^{2+} / \mathrm{Mg}^{2+}(0.6 / 1 \mathrm{mM})$ with $50 \mu \mathrm{l}$ of buffer (control) or with $50 \mu \mathrm{l}$ of the various toxin combinations (Table 1) for the indicated time periods at $37^{\circ} \mathrm{C}$. The appropriate supernates of stimulated cells were analysed for enzymes, histamine or IL-8.

\section{Histamine release from human basophilic granulocytes}

The washed cells $\left(5 \times 10^{6} \mathrm{LMB} / 500 \mu \mathrm{l}\right)$ were stimulated in the presence of $\mathrm{Ca}^{2+}(1 \mathrm{mM})$ and $\mathrm{Mg}^{2+}$ $(0.5 \mathrm{mM})$ with $50 \mu \mathrm{l}$ of PBS (buffer control), with fMLP $\left(10^{-4} \mathrm{M}\right)$, with Luk-PVL (S, F, S + F components) or with $\gamma$-haemolysin (S, F, S $+\mathrm{F}$ components) for $60 \mathrm{~min}$ at $37^{\circ} \mathrm{C}$. Cells were centrifuged for $15 \mathrm{~min}$ at $300 \mathrm{~g}$, deproteinised by the addition of $\mathrm{HClO}_{4}(2 \%$, $2 \mathrm{ml}$ ) and subsequently analysed for histamine content by the flurophotometric analyser technique (Autoanalyser Technicon, Bad Vilbel, Germany) [11]. Histamine dihydrochloride dissolved in $\mathrm{HCLO}_{4} \quad 2 \%$ served as a control. Cells in the presence of buffer and the bacterial supernate at the appropriate dilution served as negative controls. For the determination of the total cellular histamine content $(100 \%)$ the cells were disrupted by the addition of $2 \mathrm{ml}$ of $\mathrm{HClO}_{4}$ [11].

\section{IL-8 assay}

IL-8 release was determined by a sandwich ELISA according to Bazzoni et al. [14]. Each well of a 96-well plate (Nunc Maxisorb, Roskilde, Denmark) was precoated overnight at $4^{\circ} \mathrm{C}$ with $100 \mu \mathrm{l}$ of PBS/Tween 20 $(0.1 \%)$ containing anti-IL-8 antibodies at a concentration of $5 \mu \mathrm{g} / \mathrm{ml}$. The plates were washed three times with PBS/Tween, the appropriate samples or IL-8 standard (recombinant human IL-8; Calbiochem, Bad Soden, Germany) were added and incubation proceeded for $2 \mathrm{~h}$ at $37^{\circ} \mathrm{C}$. Thereafter, alkaline phosphatase-linked anti-IL-8 antibody was added. After addition of $p$ nitrophenylphosphate $(15 \mathrm{mg} / \mathrm{ml})$ for quantification, an ELISA reader and Mikrotek software (SLT Labinstruments, Crailsheim, Germany) were used to determine the amount of IL-8 released. 


\section{Determination of $\beta$-glucuronidase release}

The release of $\beta$-glucuronidase was determined as described previously [11]. Enzyme activities were calculated as the percentage of the total enzyme activities available after sonication of unstimulated PMNL ( $10^{7}$ cells).

\section{Chemiluminescence response of human granulocytes}

Oxygen radical production was monitored by luminolenhanced chemiluminescence as described elsewhere [7]. PMNL $\left(1 \times 10^{6}\right.$ cells $/ 320 \mu 1$ of PBS $)$ were incubated in the presence of $0.6 \mathrm{mM}$ calcium and $1 \mathrm{mM}$ magnesium and $0.25 \mathrm{~mm}$ luminol for $c .15 \mathrm{~min}$ at $37^{\circ} \mathrm{C}$ until a stable signal was obtained. Subsequently, $50 \mu 1$ of PBS (buffer control) or phorbol 12-myristate 13-acetate (PMA; $10^{-8} \mathrm{M}$ ) or $\mathrm{N}$-formyl-methionylleycyl-phenylalanine (fMLP) $\left(10^{-4} \mathrm{M}\right)$ or the appropriate samples were added. The production of oxygen radicals (chemiluminescence) was monitored in a Lumacounter M2080 (Lumac, Schaesberg, The Netherlands) over the indicated time periods.

PMNL were treated with PMA $\left(10^{-8} \mathrm{M}\right)$ in the absence or presence of the various potential toxins at the indicated concentrations to study the modulation of PMA-induced chemiluminescence response. The production of oxygen radicals (chemiluminescence) was monitored in a Lumacounter M2080 over the indicated time periods.

\section{Statistical analysis}

All data were calculated as means and standard deviations $(n=3)$ from three different donors. The significance was evaluated by Student's $t$ test for independent means.

\section{Results}

\section{Cellular activation}

Previously studies showed that the Panton-Valentineleukocidin (Luk-PVL) is a potent inducer for inflammatory mediator release from human granulocytes and monocytes [9-11]. The present study analysed whether the toxin concentrations, composed of the $\mathrm{S}$ and $\mathrm{F}$ component, are more, similar, or less active than LukPVL. Inflammatory mediator release was analysed preformed as well as newly generated; these are important in non-specific host defence against invading micro-organisms or their toxins, or both. The experimental design was chosen from previous experiments [11]. Human PMNL $\left(10^{7}\right.$ cells $\left./ 500 \mu 1\right)$ or a human LMB cell suspension $\left(5 \times 10^{6} \mathrm{LMB} / 500 \mu \mathrm{l}\right)$ were incubated in the presence of the various toxins ( $\mathrm{S}+\mathrm{F}$ components) at different concentrations $(2000,1000,500,50,0.5,5$ or $0 \mathrm{ng}$ ) for up to $60 \mathrm{~min}$ at $37^{\circ} \mathrm{C}$ as described in Materials and methods. Cells were stimulated with the individual toxin subunits (S, F) separately as controls. Cells were analysed for viability and for their ability to generate oxygen metabolites; the cell supernates were analysed for enzyme activities ( $\beta$-glucuronidase) and for histamine release, as well as for IL-8 content.

\section{Viability}

Trypan blue staining was used as a measure of membrane and cellular integrity. The cytotoxic activities of the six possible combinations of type $\mathrm{S}$ and type $\mathrm{F}$ components revealed that all of them were able to promote lysis of human PMNL (Table 2) and human LMB (data not shown). When tested alone, none of the five protein components induced any appreciable toxicity with PMNL or LMB. Treatment of PMNL with toxin at a concentration of $2000 \mathrm{ng}$ (each component) showed cytotoxic effects for PMNL as verified by an increase in trypan blue-positive cells from $5 \mathrm{SD} 2 \%$ (unstimulated cells) up to $50-80 \%$ independent of the toxin used (Table 2). However, the toxins $\mathrm{HlgA} / \mathrm{HlgB}$ and $\mathrm{HlgA} /$ LukF-PVL did not induce an increase in trypan blue-positive cells at a concentration of $500 \mathrm{ng}$ (Table 2). Similar results were obtained with the LMB cell suspension. Within the LMB cell suspension the basophilic granulocytes (the source for histamine) and monocytes (the source for IL-8) showed similar susceptibilities towards the toxins. Therefore, in further experiments the maximal toxin concentration used was $1000 \mathrm{ng}$ (each component). At toxin concentrations of $\leqslant 50 \mathrm{ng}$ (each component) no toxin combination induced an increase in trypan bluepositive cells (data not shown).

Table 2. Viability of toxin-treated PMNL

\begin{tabular}{|c|c|c|c|c|c|}
\hline \multirow[b]{2}{*}{ Toxin combination } & \multicolumn{2}{|c|}{ Current name of } & \multicolumn{3}{|c|}{$\begin{array}{c}\text { Percentage }^{*} \text { of positive trypan blue-stained PMNL after } \\
\text { treatment with the toxin combinations } \\
\text { (ng of each component) }\end{array}$} \\
\hline & $\mathrm{S}$ component & F component & 20000 & 500 & 50 \\
\hline Luk-PVL & LukS-PVL & LukF-PVL & $82(10)$ & $37(8)$ & $5(2)$ \\
\hline HlgA/HlgB & $\mathrm{H} \lg \mathrm{A}$ & $\mathrm{HlgB}$ & $70(12)$ & $12(2)$ & $4(1)$ \\
\hline $\mathrm{HlgC} / \mathrm{HlgB}$ & $\mathrm{HlgC}$ & HlgB & $60(6)$ & $42(12)$ & $5(1)$ \\
\hline LukS-PVL/HlgB & LukS-PVL & HlgB & $67(15)$ & $38(6)$ & $6(3)$ \\
\hline HlgA/LukF-PVL & $\mathrm{H} \operatorname{lgA}$ & LukF-PVL & $82(4)$ & $12(7)$ & $2(1)$ \\
\hline HlgC/LukF-PVL & $\mathrm{HlgC}$ & LukF-PVL & $51(15)$ & $35(4)$ & $2(1)$ \\
\hline
\end{tabular}

${ }^{*}$ Data represent mean values (SD) of three independent experiments. 


\section{Chemiluminescence}

All toxins led to an increase in the chemiluminescence (CL) response in a dose-dependent manner up to a concentration of $50 \mathrm{ng}$ of each component. Fig. 1 shows the results for toxin concentrations of $50 \mathrm{ng}$ and $500 \mathrm{ng}$ (each component). As is apparent from Fig. 1, the various toxins differed markedly in the profile of induced CL response. In this regard, the comparative potency for the induction of a chemiluminescence response was as follows: LukS-PVL/LukF-PVL $=$ LukS-PVL/HlgB > HlgC/LukF-PVL $>\mathrm{HlgC} / \mathrm{HlgB}>$ $\mathrm{HlgA} / \mathrm{LukF}-\mathrm{PVL}=\mathrm{HlgA} / \mathrm{HlgB}$. At a concentration of $500 \mathrm{ng}$ (each component) (Fig. 1b) an increase in chemiluminescence response as compared to unstimulated cells was observed only with HlgA/LukF-PVL and $\mathrm{Hlg} \mathrm{A} / \mathrm{HlgB}$. The other combinations failed to induce a $\mathrm{CL}$ response, probably because of cytotoxic effects. Further experiments were performed to analyse whether the toxins differed with regard to their modulatory effects on CL response towards PMA which is a potent inducer of the CL. For this purpose human PMNL were treated with PMA in the absence (control) or in the presence of the various toxins. Fig. $1 \mathrm{c}$ and $\mathrm{d}$ shows the results for toxin concentrations of 50 and $500 \mathrm{ng}$ (each component). It is evident from Fig. 1c that toxins at a concentration of $50 \mathrm{ng}$ did not modulate the PMA-induced CL response. However, at a toxin concentration of $500 \mathrm{ng}$, the PMA-induced CL response was modulated (Fig. 1d). As expected, the two toxins $\mathrm{H} \lg \mathrm{A} / \mathrm{H} \operatorname{lgB}$ and $\mathrm{H} \lg \mathrm{A} / \mathrm{LukF}-\mathrm{PVL}$ (which are weak inducers of chemiluminescence response), suppressed the PMA-induced CL response to a significantly lesser degree than the other toxins due to their enhanced cytotoxic activity on human PMNL.
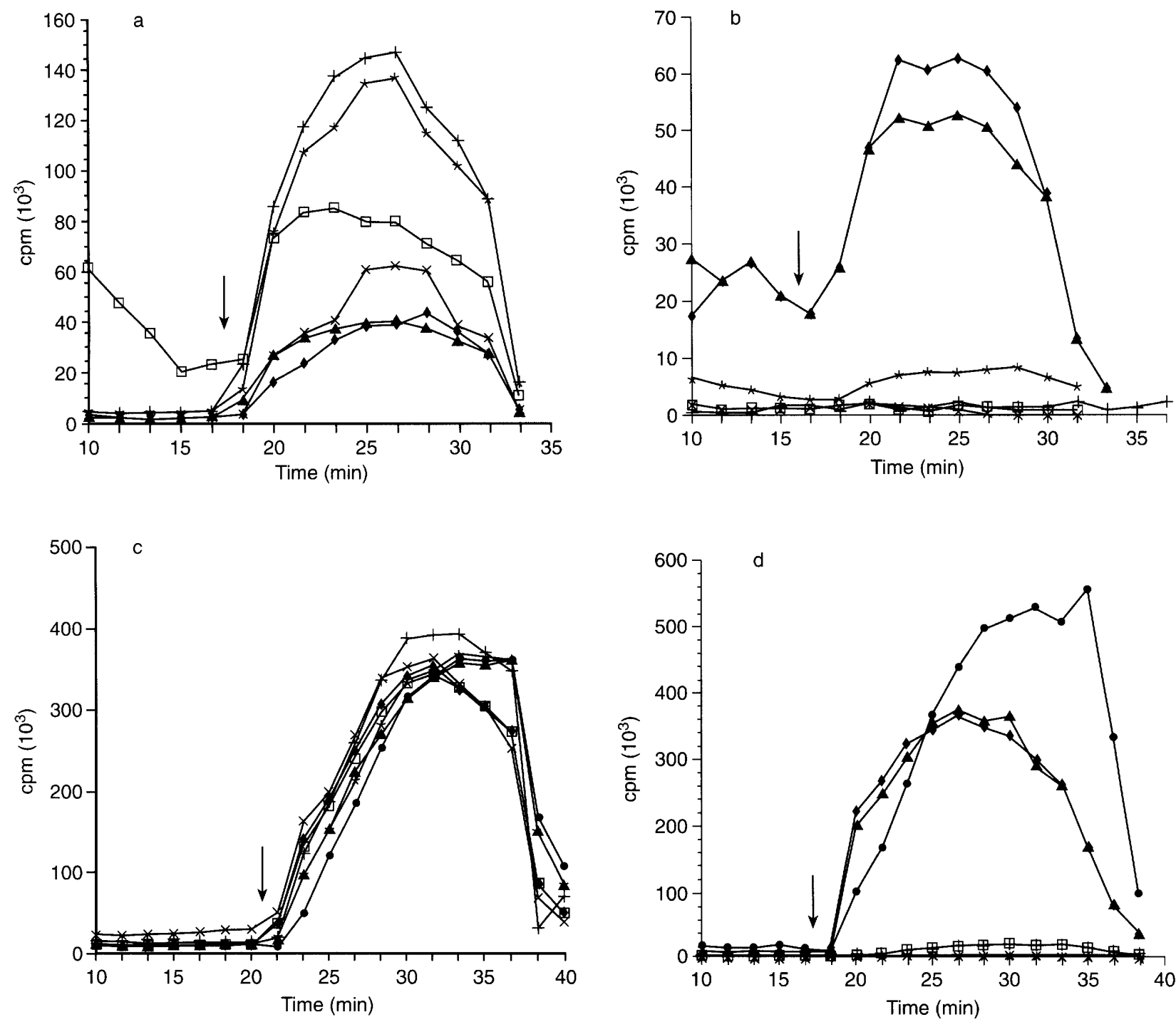

Fig. 1. Chemiluminescence response from human PMNL stimulated with various toxins at a concentration (each component) of $50 \mathrm{ng}(\mathbf{a}, \mathbf{c})$ and $500 \mathrm{ng}(\mathbf{b}, \mathbf{d})$ for up to $50 \mathrm{~min}$ at $37^{\circ} \mathrm{C}$. Stimulation was performed in the absence (a, b) or in the presence of PMA $\left(10^{-8} \mathrm{M}\right)(\mathbf{c}, \mathbf{d})$. Buffer control values were subtracted. Data represent mean values of three independent experiments. The arrow indicates the addition of the toxins $(\mathbf{a}, \mathbf{b})$ or the addition of the toxins plus PMA (c, d). +, LukS-PVL + LukF-PVL; — - LukS-PVL/HlgB; $\square$ HlgC/LukF-PVL; $\succ$, HlgC/HIgB; - - , $\mathrm{HlgA} / \mathrm{LukF}-\mathrm{PVL} ;-\boldsymbol{\Lambda}-\mathrm{H} \lg \mathrm{A} / \mathrm{HlgB}$. 


\section{$\beta$-glucuronidase release}

Fig. 2 shows that all 'toxins' induced $\beta$-glucuronidase release from human PMNL in a dose-dependent manner. However, at all toxin concentrations tested (1000, 500 or $50 \mathrm{ng}$ of each component) the various toxins showed different activation patterns for $\beta$ glucuronidase release (Fig. 2) from human PMNL. In this regard, the comparative potency to induce $\beta$ glucuronidase release was: LukS-PVL/LukF-PVL $=$
LukS-PVL/HlgB $>$ HlgC/lukF-PVL $=$ HlgC $/ \mathrm{HlgB}>$ $\mathrm{HlgA} / \mathrm{LukF}-\mathrm{PVL}=\mathrm{HlgA} / \mathrm{HlgB}$.

\section{Histamine release}

Histamine presents a preformed mediator with potent vasodilatory effects. Fig. 3 shows the results for toxin concentrations of 500,50 and $5 \mathrm{ng}$ of each component. As with the CL response and $\beta$-glucuronidase release,

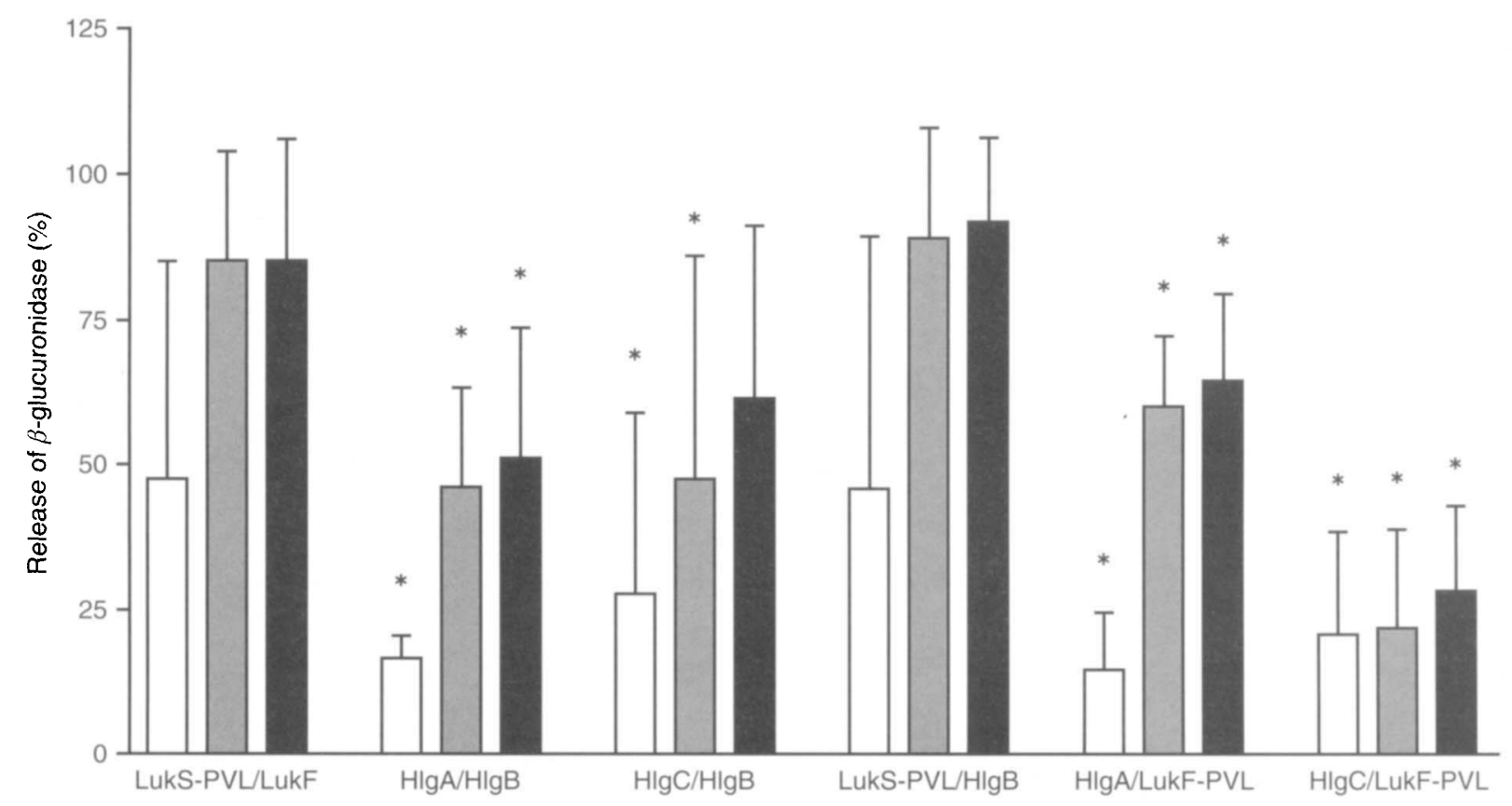

Fig. 2. Release of $\beta$-glucuronidase from human PMNL $\left(1 \times 10^{6} / 500 \mu 1\right)$ incubated in the presence of various toxins at concentrations of $50(\square), 500(\mathbf{\square})$ and $1000 \mathrm{ng}(\mathbf{\square})$ for $60 \mathrm{~min}$ at $37^{\circ} \mathrm{C}$. Ca-ionophore A23187 (Ion; $3 \mu \mathrm{M}$ ) stimulation was performed for comparison (positive control) and led to $\beta$-glucuronidase release of $32 \mathrm{SD} 5 \%$; $\beta$-glucuronidase release from unstimulated cells (buffer control) was $13.22 \mathrm{SD} 11.55 \%$. Data represent mean values and SD of five independent experiments. ${ }^{*}$ Significant difference compared to stimulation with LukS-PVL/LukF-PVL, $\mathrm{p}<0.05$.

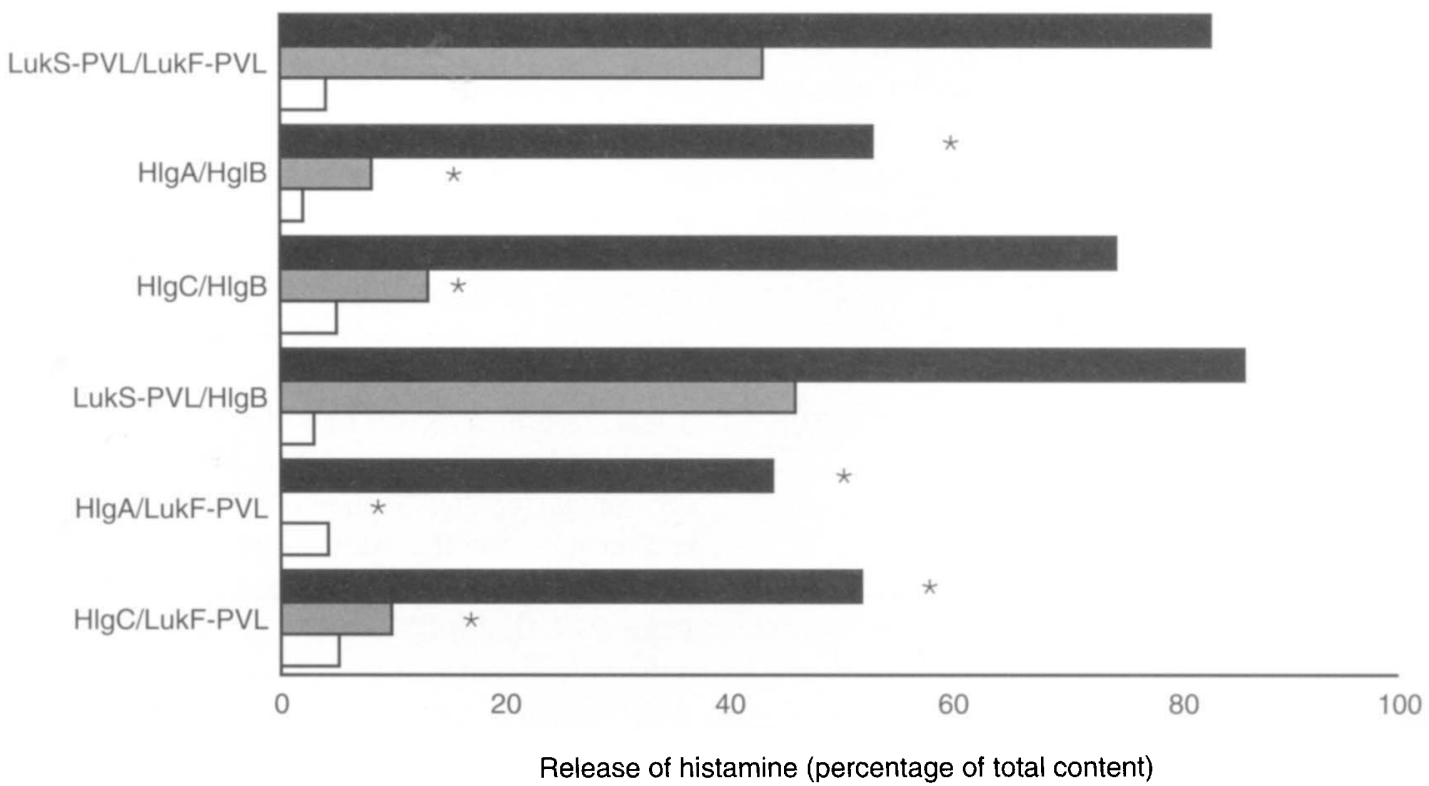

Fig. 3. Release of histamine from human basophilic granulocytes $\left(5 \times 10^{6}\right)$ stimulated by the various toxins at concentrations $5(\square), 50(\mathbb{G})$ and $500 \mathrm{ng}(\boldsymbol{\square})$ for $1 \mathrm{~h}$ at $37^{\circ} \mathrm{C}$. FMLP $\left(10^{-4} \mathrm{M}\right)$ stimulation was performed for comparison (positive control; 35 SD 7\%). Values of unstimulated cells (5 SD 3\%) were subtracted. Data are mean values of three independent experiments. ${ }^{*}$ Significant difference compared to stimulation with LukS-PVL/LukF-PVL, p $<0.05$. 
the toxins differed with regard to histamine release. Again, the comparative potency to induce histamine release was LukS-PVL/LukF-PVL = LukS-PVL/HglB $>\mathrm{HlgC} / \operatorname{lukF}-\mathrm{PVL}=\mathrm{HlgC} / \mathrm{HlgB}>\mathrm{HlgA} / \mathrm{LukF}-$ $\mathrm{PVL}=\mathrm{Hlg} \mathrm{A} / \mathrm{HlgB}$.

\section{IL-8 generation}

IL-8 represents one important chemotactic factor for PMNL. Therefore, the effects of various toxins on IL-8 release from human LMB were studied. The results are presented in Table 3. It is evident that LukSPVL/LukF-PVL and Luk-S-PVL/HlgB, already at low concentrations $(0.5 \mathrm{ng}$ of each component) were the most potent inducers of $\mathrm{IL}-8$ release, again followed by the toxins HlgC/LukF-PVL and $\mathrm{HlgC} / \mathrm{HlgB}$. The toxins containing $\mathrm{HlgA}$ as $\mathrm{S}$ component were significantly less active.

\section{Discussion}

S. aureus produces numerous toxins for which a role in staphylococcal diseases are more or less precisely characterised $[1,8,15]$. Staphylococcal synergohymenotropic toxins are able to exert toxic and biological effects on the membranes of defence cells because of the synergy of two non-associated exoproteins of class $\mathrm{S}$ and class $\mathrm{F}[1,16]$. Class $\mathrm{S}$ components were recognised as binding specifically membranes of target cells prior to the secondary interaction of class $F$ components [17]. Data from the present study indicate that class $\mathrm{S}$ and class $\mathrm{F}$ components are interchangeable and give toxins with genuine biological activity.

The Phanton-Valentine leukocidin (Luk-PVL) was reported to be strongly associated with some necrotising primary cutaneous infections such as furuncles and dermonecrosis [1,8]. Previous studies have shown that, at the molecular level, sublytic amounts of LukPVL induce granule secretion from human neutrophilic granulocytes and the release of leukotriene $\mathrm{B}_{4}$, as well as that of IL-8 [9-11]. The results obtained may explain the chemotactic activities of PMNL and the

Table 3. Il-8 release from human LMBs

\begin{tabular}{lccc}
\hline Toxin & \multicolumn{2}{l}{$\begin{array}{l}\text { Mean (SD) IL-8 released (ng/ml) by the } \\
\text { toxin combination (ng of each component) }\end{array}$} \\
\cline { 2 - 4 } & 50 & 5 & 0.5 \\
\hline LukS-PVL/LukF-PVL & $15(4)$ & $22(8)$ & $35(6)$ \\
LukS-PVL/HlgB & $37(8)$ & $35(12)$ & $42(8)$ \\
HlgC/LukF-PVL & $52(6) \dagger$ & $30(8)$ & $18(3) \dagger$ \\
HlgC/HlgB & $48(5) \dagger$ & $37(7)$ & $18(3) \dagger$ \\
HglA/LukF-PVL & $9(3) \dagger$ & $10(2) \dagger$ & $19(9) \dagger$ \\
HglA/HglB & $12(8) \dagger$ & $11(1) \dagger$ & $18(4) \dagger$ \\
\hline
\end{tabular}

${ }^{*}$ Data represent values $\pm \mathrm{SD}$ of three independent experiments; baseline values were subtracted.

†Significant difference compared to cells stimulated with LukSPVL/LukF-PVL. inflammatory lesions observed in an animal model after intradermal injection of the toxin. The biological activity of $\gamma$-haemolysin (HlgA-HlgB and HlgC-HlgB) in a human in-vitro model has not been investigated before [1]. Both combinations of the staphylococcal $\gamma$ haemolysin induced chemiluminescence response, enzyme, histamine and IL-8 release from human granulocytes to a significantly lower degree when compared with Luk-PVL. Furthermore, both combinations were significantly less toxic towards human PMNL. In addition, the data clearly show that HlgA and $\mathrm{HlgC}$, both S-like components, differ in their biological activities. In this regard, HlgA-HlgB is less active than $\mathrm{HlgC} / \mathrm{HlgB}$.

In contrast to the high frequency of $\gamma$-haemolysin genes in $S$. aureus, Luk-PVL genes are less frequently distributed, as they are encountered in only $2 \%$ of randomly obtained isolates $[6,8]$. However, clinical isolates were obtained that harboured and expressed not only the two genes coding for Luk-PVL but also the three genes encoding $\gamma$-haemolysin [5]. Results obtained by secretion experiments clearly show that preliminary aggregation of the two components of the toxin is not necessary for insertion of the whole toxin into the membrane. If all five proteins are produced in vivo, the association of a given protein of class $\mathrm{S}$ with a given protein of class $F$ could generate six $S+F$ molecular combinations produced by all PVL-producing strains. Thus, six possible combinations of type $\mathrm{S}$ and type $F$ proteins occur in such strains and lead to six toxin combinations which might express different significances in bacterial pathogenesis. This study presents evidence that all six potential toxins interact with human PMNL, basophilic granulocytes and monocytes to release inflammatory mediators. However, the various toxins differed markedly in their potency to induce and modulate the $\mathrm{CL}$ response, to induce enzyme ( $\beta$-glucuronidase), histamine release and IL- 8 generation. The data clearly show that the individual subunits ( $\mathrm{S}$ and $\mathrm{F}$ ) differ in their activities. In this regard, the following activities were obtained for the S components: LukS-PVL $>\mathrm{HlgC}>\mathrm{HlgA}$. The molecular mechanisms underlying the distinct interaction of the various $\mathrm{S}$ components with the target membrane has not been studied yet. The $\mathrm{F}$ components, LukF-PVL and $\mathrm{HlgB}$, had similar activity. These results indicate that the potency of a toxin to induce inflammatory mediator release is predominantly determined by the $\mathrm{S}$ component. The $\mathrm{S}$ component is responsible for the initial step in toxin action, i.e., binding to membranes [16, 17]. Therefore, toxins LukS-PVL/LukF-PVL and LukS-PVL/HlgB were the most potent inducers of inflammatory mediator release from human granulocytes, followed by $\mathrm{HlgC} / \mathrm{LukF}$ PVL and HlgC/HlgB. The toxins HlgA/LukF-PVL and $\mathrm{HlgA} / \mathrm{HlgB}$ were less potent inducers of inflammatory mediator release than the other toxins. These results parallel in-vivo models with rabbit skin. In this regard, $\mathrm{HlgA} / \mathrm{LukF}-\mathrm{PVL}$ and $\mathrm{HlgA} / \mathrm{HlgB}$ did not 
induce acute inflammatory lesions when these toxins were injected intradermally into rabbit skin.

In the present experiments, inflammatory mediator release was only apparent when human PMNL were treated with both components simultaneously or when they were treated in the following sequence: $S$ component, washing the target cells, addition of the F component. The opposite sequence, i.e., F component, washing of the target cells, then addition of the $\mathrm{S}$ component, did not induce any biological activity (data not shown) $[11,16,17]$. The data clearly show that these components were non-cytotoxic when tested individually and failed to induce mediator release from human effector cells. These results are supported by results from in-vivo testing on rabbit skin. All five components had minimal effects when injected intradermally alone in rabbit skin. Only high amounts of protein $(30000 \mathrm{ng})$ induced transient inflammatory lesions (data not shown).

Although crucial in defence against infection, neutrophils and their toxic contents and products have been implicated in the pathogenesis of tissue injury in important inflammatory diseases $[18,19]$. In this regard the neutrophil generates toxic oxygen metabolites and contains powerful degradative granule enzymes and toxic cationic proteins. The chemotactic cytokine IL-8 was found to be highly correlated with neutrophil cellular infiltration and their activation $[20,21]$. Histamine, released by mast cells or basophils, for example, has been implicated as a potentially important mediator of inflammatory disease. In addition to its vasodilatory action, histamine can also affect the release of soluble mediators from other cell types. It is concluded that the potency of the various toxin combinations to induce inflammatory mediator release may reflect their significance in disease. These findings might explain why staphylococcal infection may appear as local or generalised infection to a different degree.

W. König was supported by Bundesminister des Inneren.

\section{References}

1. Prevost G, Supersac G, Colin DA et al. The new family of leucotoxins from Stophylococcus aureus: structural and biological properties. In: Freer $\mathrm{JH}$ et al. (eds) Bacterial protein toxins. Zentralbl Bakteriol Suppl 24. Stuttgart, Gustav Fischer Verlag. 1994: 284-293.

2. Supersac G, Prevost G, Piemont Y. Sequencing of leucocidin from Staphylococcus aureus P83 suggests that staphylococcal leucocidins and gamma-hemolysin are members of a single, two-component family of toxins. Infect Immun 1993; 61: 580-587.

3. Guyonnet F, Plommet M. [Gamma hemolysin of Staphylococ- cus aureus: purification and properties.] Ann Inst Pasteur 1970; 118: $19-33$

4. Cooney J, Kienle Z, Foster TJ, O'Toole PW. The gammahemolysin locus of Staphylococcus aureus comprises three linked genes, two of which are identical to the genes for the $\mathrm{F}$ and $\mathrm{S}$ components of leukocidin. Infect Immun 1993; 61: $768-771$

5. Kamio Y, Rahmann A, Nariya H, Ozawa T, Izaki $K$. The two staphylococcal bi-component toxins, leukocidin and gammahemolysin, share one component in common. FEBS Lett 1993; 321: $15-18$.

6. Prevost G, Couppie P, Prevost P et al. Epidemiological data on Staphylococcus aureus strains producing synergohymenotropic toxins. J Med Microbiol 1995; 42: 237-245.

7. Finck-Barbancon V, Prevost G, Piemont Y. Improved purification of leukocidin from Staphylococcus aureus and toxin distribution among hospital strains. Res Microbiol 1991; 142: $75-85$.

8. Criibier B, Prévost G, Couppie P, Finck-Barbancon, P, Grosshans P, Piémont Y. Staphylococcus aureus leukocidin: a new virulence factor in cutaneous infections. An epidemiological and experimental study. Dermatology 1993; 185: $175-180$.

9. Hensler T, König B, Prévost G, Piémont Y, Köller M, König W. Leukotriene B4-generation and DNA fragmentation induced by leukocidin from Staphylococcus aureus: protective role of granulocyte-macrophage colony-stimulating factor (GM-CSF) and G-CSF on human neutrophils. Infect Immun 1994; 62: 2529-2535.

10. König B, Köller M, Prévost $G$ et al. Activation of human effector cells by different bacterial toxins (leukocidin, alveolysin, erythrogenic toxin A), generation of interleukin-8. Infect Immun 1994; 62: 4831-4837.

11. König B, Prévost G, Piémont Y, König W. Effects of Staphylococcus aureus leucocidins on inflammatory mediator release from human granulocytes. $J$ Infect Dis 1995; 171: 607-613.

12. Prévost G, Cribier B, Couppié $P$ et al. Panton-Valentine leucocidin and gamma-hemolysin from Staphylococcus aureus ATCC 49775 are encoded by distinct genetic loci and have different biological activities. Infect Immun 1995; 63: 4121-4129.

13. Boyum A. Isolation of lymphocytes, granulocytes and macrophages. Scand J Immunol 1976; Suppl 5: 9-15.

14. Bazzoni F, Cassatella MA, Rossi F, Ceska M, Dewald B, Baggiolini M. Phagocytosing neutrophils produce and release high amounts of the neutrophil-activating peptide-1/interleukin 8. J Exp Med 1991; 173: 771-774.

15. Alouf JE, Knöll H, Köhler W. The family of mitogenic, shockinducing and superantigenic toxins from staphylococci and streptococci. In: Alouf JE, Freer JH (eds) Sourcebook of bacterial protein toxins. London, Academic Press. 1991: $376-314$

16. Finck-Barbançon V, Duportail G, Meunier O, Colin DA. Pore formation by a two-component leukocidin from Staphylococcus aureus within the membrane of human polymorphonuclear leukocytes. Biochim Biophys Acta 1993; 1182: 275-282.

17. Colin DA, Mazurier I, Sire S, Finck-Barbancon V. Interaction of the two components of leukocidin from Staphylococcus aureus with human polymorphonuclear leukocyte membranes: sequential binding and subsequent activation. Infect Immun 1994; 62: 3184-3188.

18. Weiss SJ. Tissue destruction by neutrophils. $N$ Engl J Med 1989; 320: $365-376$.

19. König W, Schönfeld W, Raulf $M$ et al. The neutrophil and leukotrienes: role in health and disease. Eicosanoids 1990; 3: $1-22$.

20. Brom J, König W. Cytokine-induced (interleukin-3, -6 , and -8 and tumour necrosis factor- $\beta$ ) activation and deactivation of human neutrophils. Immunology 1992; 75: 281-285.

21. Baggiolini $M$. Neutrophil activation and the role of interleukin8 and related cytokines. Int Arch Allergy Immunol 1992; 99: 196-199. 